\title{
Self-Assessment on Information Literacy Competency of Students in Indonesia-Papua New Guinea Border Area During The COVID-19 Epidemic
}

\author{
Latika Ari Prihandoko \\ \{prihandoko@unmus.ac.id\} \\ Department of English Literature, Universitas Musamus, Papua, Indonesia
}

\begin{abstract}
COVID-19 requires students to be able to study independently, supported by information literacy skills. The purpose of this study is to conduct a self-assessment on the information literacy competency of students that they apply in learning activities during the COVID-19 outbreak in terms of gender and ethnicity. Respondents conduct a selfassessment of their information literacy competency. The total number of respondents are 200 from four tertiary institutions in the Indonesian-Papua New Guinea border area. In general, students have a moderate level of information literacy competence. Based on the findings of this study, females of non-Papuan ethnicity had the best level of information literacy among the other categories of respondents. The results suggest the following action that requires particular policies that are expected to improve this ability. The blended learning model is assumed to be most suitable for students in Papua who have limited infrastructure for learning activities during the COVID-19 epidemic.
\end{abstract}

Keywords: information literacy, self-assessment, gender, ethnicity, COVID-19

\section{Introduction}

The emergence of the coronavirus (COVID-19) pandemic presents a challenge for a country. The epidemic that emerged from China spread rapidly to various places in the world [1]. The initial spread of COVID-19 in Indonesia began in February 2020 with the Jakarta cluster, two months after the emergence of the coronavirus in Wuhan, China. The government is taking several strategic steps to be implemented in the face of a pandemic in the form of an independent isolation program, social restrictions, physical restrictions, prohibiting homecoming, and large-scale social limits. Types of businesses and services such as retail stores, education, places of worship, government offices, and public facilities are closed to reduce the spread of COVID-19.

Policies implemented in Papua related to COVID-19, especially on Animha lands, are thought to have an impact on the academic sector. Papua implements restrictions in the form of closing educational facilities from elementary to tertiary levels. The closure of educational facilities has been carried out by various governments around the world to prevent the spread of COVID-19 because educational facilities are a place for thousands of students and academic staff to interact. Students and academic staff are forced to adapt to these circumstances to change traditional (face-to-face) educational patterns using technological facilities. In China itself, since 
the spread of the COVID-19 epidemic, universities have to get used to migrating massively from face-to-face learning to online learning [2]. The massive migration of learning taking place in other parts of the country, along with the massive spread of the COVID-19 epidemic [3-7].

The demands for educational transformation were imposed in a very brief period so that not all educational institutions were ready to carry out the transformation of online learning. The teaching staff faces problems in the form of limited experience using online learning, unprepared infrastructure in the form of facilities, and limited support from the technical team $[2,4,6]$. On the other hand, the challenges that arise are not only related to technical problems but also related to students' attitudes towards learning, such as inappropriate content of learning materials, lack of discipline, and a home learning environment that is not supportive of distance learning [2]. The problem in the transformation of distance learning that must be carried out by the academic community requires determination and consistency to be able to implement changes by continuously adapting and be able to increase the effectiveness of distance learning that will continue until the Covid-19 epidemic can end.

Students need provisions in carrying distance learning, including the need for information literacy skills. This ability will accompany students to become independent learners. [8] emphasizes that information literacy has a close relationship to foster critical thinking skills in students. Meanwhile, [9] identified that information literacy has a relationship with student motivation and confidence in searching for information using the internet. With proper information literacy skills, students are expected to be able to follow the transformation phase of distance learning without any obstacle.

Research related to the impact of COVID-19 on the world of education is still limited. Much research focus explores from the medical side and the economic side. In particular, in higher education in the global realm, research is still very limited on the effect of COVID-19 on assessments of STEM synthesis, dental education, and surgeon education chick. Meanwhile, in the context of Indonesia itself, there are only a few studies including the perception of mathematics teachers in implementing e-learning [10], the experience of using remote learning for students during the COVID-19 period [11], the influence of COVID-19 on the concept of independent learning [12]. Previous researches neglect the context of rural areas where facilities and infrastructure conditions are generally different from the western part of Indonesia.

This research will focus on exploring information literacy skills in universities located in rural areas / the border between Indonesia and Papua New Guinea. Information literacy skills are considered important for students to master because the distance learning model requires students to be independent learners. By exploring the level of student literacy skills, it is hoped that they can find empirical data that will be used for curriculum development, learning models, and policies to support distance learning, especially during the COVID-19 pandemic.

The success of students in the academic context, especially in distance learning is inseparable from the academic abilities of the students. The ability of student information literacy is not a single circumstance to be improved through learning because many factors influence the indicators of this ability. Difficulties in information literacy competency are not only experienced by both regional and international students [13]. [14] has identified that the ability of students to read academic texts and the ability to practice writing is very closely related to gender, culture, and educational background. Moreover, the same view was expressed by previous research which identified that gender has a role in the ability of information literacy 
[15-17]. However, research findings also underline that information literacy is independent without gender influence [18-20]. The previous studies related to the influence of gender and the ability of information literacy may not be generalized to a wider scope related to student academic life.

The ability of information literacy is crucial to be mastered by students through independent learning or intervention from the university. The university should be able to be a pioneer in improving information literacy competency with a long-term goal of having students autonomous when dealing with all projects that require sound and quality sources of information [21]. The ability of information literacy is a shared responsibility in a wider scope of academic literacy [22]. A harmonious synchronization between librarians and the academic life of students is needed [23]. Librarians have a responsibility to get out of their comfort zones to be able to work with students in various disciplines [24]. [25] added that academic ability is formed from the collaboration between the academic community consisting of librarians, staff, and academics.

Students become the main actors in obtaining information literacy competency, need solid support from academia, where students carry out their studies. The importance of information literacy for students to succeed in their academic lives has received special attention from previous studies. In the global sphere, [23] describes the behavior and perceptions of students majoring in history toward information literacy. Also, active learning carried out by students with module support can improve the information literacy and academic abilities of international students [24]. Moreover, belief in importance and self-efficacy is an important part of the core capabilities of information literacy [23]. [26] found the context of academic literacy, which lacked support from universities through ICT involvement and information literacy. Meanwhile, [27] found that teaching staff and the use of social media as learning media affect the level of digital literacy skills of students. Previous research in the global realm suggested that internal and external factors of students influenced the ability to equip information literacy competency to students.

At the beginning of its emergence, information literacy only rests on terms that are conical in the library and its staff. In the last 30 years, the term information literacy has become popular in the academic world. However, awareness to teach it in the new class emerged in 2002 [28]. The teacher starts to look for ways to teach information literacy that, at first glance, seems simple, but it is also quite complicated. When talking about information literacy, the terms that follow are always related to searching, evaluating, processing, and communication dissemination information. Multiple stages and processes ultimately raise a big question mark in the world of education about how to teach information literacy in the classroom and what challenges arise in practice [23]. In the academic world, educators need to ensure the curriculum can accommodate and develop abilities students so students can demonstrate their ability to complete assignments based on their competency [29].

In the academic world, information literacy has a key role in making students successful. There are three main components in student academic development consisting of self-efficacy, motivation, and information literacy [30]. Furthermore, these three components also influence students' abilities and preferences in choosing learning resources [23]. Students need the ability to search for information to effectively communicate that information through the process of analysis to the organization of information [26]. Moreover, this ability becomes the most 
representative ability in the academic world if accompanied by decent digital competency [31].This Word document can be used as a template for papers to be published in EAI Core Proceedings. Follow the text for further instructions on text formating, tables, figures, citations and references.

\section{Methodology}

The research used a survey strategy with a descriptive quantitative approach. The study was employed random sampling technique and gather respond from 200 students. Respondents came from four universities in one district in Papua, which is directly adjacent to Papua New Guinea. Students have different socioeconomic backgrounds. Students come from two major ethnicities, namely Papuan and non-Papuans. The types of supporting facilities for distance learning owned by students are also minimal because not all have laptops or smartphones. Data obtained from questionnaires distributed to students in August 2020. For students who have supporting facilities in the form of laptops/smartphones, and internet quotas, the instruments are distributed via Google form. Meanwhile, for students who do not have the supporting facilities, students fill out a paper-based questionnaire. From the data collection process, 120 responses were obtained from Google form, and 80 responses were obtained from paper-based questionnaires. Demographic data of respondents, as shown in Figure 1 and Figure 2.

Gender

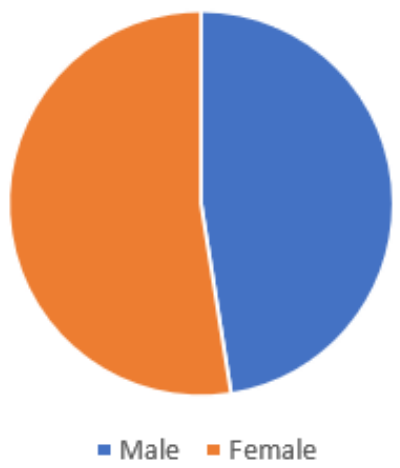

Ethnicity

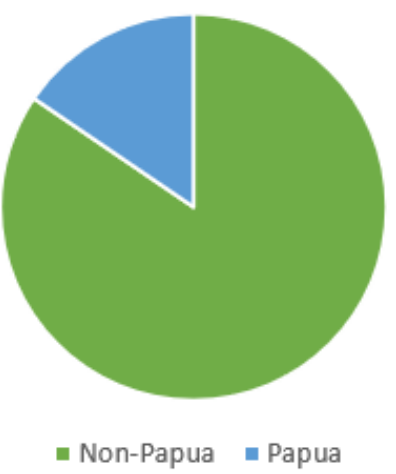

Fig 1. Gender and Ethnicity of Respondents 


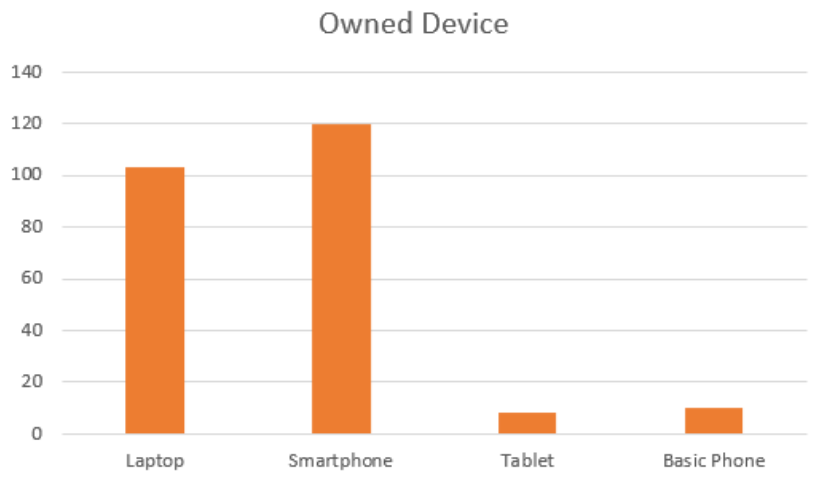

Fig 2. Respondents' Owned Devices

The research instrument was developed from previous research [32], which was translated into Indonesian to facilitate respondents quickly filling the questionnaire. The instrument is in the form of a close-ended questionnaire with seven Likert scales. Furthermore, four Indonesian lecturers conducted instrument validation, and the researcher was conducted pilot testing with 50 students to determine the reliability level of the instrument. The reliability and validity tests were carried out using SPSS 23, and the results showed a reliability test of 0.73 and a validity test of 0.44 , which concluded that the instrument was feasible to use.

The instrument contains 21 questions that aim to carry out self-assessment of students' literacy competence. The instrument also aims to determine the students' strategies to learn information literacy competence. Furthermore, some questions are used to obtain respondent demographic data, which will be used to support data analysis. The data that have been obtained are processed using SPSS 23 to determine the mean and SD. Furthermore, the information literacy competency level uses the interpretation framework in the form of 1.3-3.5 (weak), 3.65.8 (moderate), and 5.9-7.0 (high) is applied to interpret the results of data processing. In addition, the data of students' strategies of obtaining the information literacy competence are analyzed using frequency chart.

\section{Result and Discussion}

The first objective of this study is to determine the level of information literacy competency through self-assessment. Descriptive statistical data processing is used to determine the level of student information literacy competency. Overall, the data shows that students have information literacy competencies at a moderate level $(\overline{\mathrm{x}}=5.1)$. Table 3.1 presents an overview of these capabilities. 
Table 1. Self-assessment on Students' Literacy Competence

\begin{tabular}{|c|c|c|c|}
\hline No & Statements & $\overline{\mathbf{x}}$ & $\sigma$ \\
\hline 1 & $\begin{array}{l}\text { The ability to download scientific information from the internet is } \\
\text { needed to make academic assignments. }\end{array}$ & 6.15 & 1.17 \\
\hline 2 & $\begin{array}{l}\text { In completing academic assignments, students need information } \\
\text { search strategies using keywords in search engines (google/google } \\
\text { scholar). }\end{array}$ & 4.46 & 1.89 \\
\hline 3 & $\begin{array}{l}\text { Students will be interested in making academic assignments in } \\
\text { which the materials must be searched manually (offline) from } \\
\text { printed sources of research books/research articles. }\end{array}$ & 4.69 & 1.89 \\
\hline 4 & $\begin{array}{l}\text { Students find it easy to find the right keywords to find information } \\
\text { from the internet for academic assignments. }\end{array}$ & 5.1 & 1.81 \\
\hline 5 & $\begin{array}{l}\text { Students need the ability to assess the quality of information } \\
\text { sources to complete academic assignments }\end{array}$ & 4.41 & 1.91 \\
\hline 6 & $\begin{array}{l}\text { The ability to find relevant information from the internet is useful } \\
\text { for students in completing academic assignments. }\end{array}$ & 5.62 & 2.04 \\
\hline 7 & $\begin{array}{l}\text { It is easy to assess the quality of information that is obtained from } \\
\text { the internet }\end{array}$ & 4.87 & 1.73 \\
\hline 8 & $\begin{array}{l}\text { When reading sources of scientific information, it is challenging to } \\
\text { distinguish between the opinion of the author or the part of the } \\
\text { facts. }\end{array}$ & 5.34 & 1.39 \\
\hline 9 & $\begin{array}{l}\text { Knowing the structure/framework of scientific information sources } \\
\text { (research books/journals) is required to complete academic } \\
\text { assignments. }\end{array}$ & 5.62 & 2.05 \\
\hline 10 & $\begin{array}{l}\text { In completing academic assignments, students must be able to } \\
\text { adapt scientific information sources as an assignment framework. }\end{array}$ & 5.66 & 1.27 \\
\hline 11 & $\begin{array}{l}\text { Students will be challenged if they get an assignment to identify the } \\
\text { structure/framework of scientific papers/research journals. } 4.73 \\
1.74\end{array}$ & 4.73 & 1.74 \\
\hline 12 & $\begin{array}{l}\text { Students feel confident enough in completing academic } \\
\text { assignments that must be adapted from scientific information } \\
\text { sources (research books/journals). }\end{array}$ & 5.41 & 1.55 \\
\hline 13 & $\begin{array}{l}\text { To complete academic assignments, students need the ability to } \\
\text { type using document processing software (Ms. Office). }\end{array}$ & 5.76 & 2.12 \\
\hline 14 & $\begin{array}{l}\text { In completing academic assignments, students need to pay attention } \\
\text { to the professional ethics of academics (not copy-paste / not } \\
\text { cheating). }\end{array}$ & 4.19 & 2.16 \\
\hline 15 & $\begin{array}{l}\text { If the lecturer assigns me to upload assignments using the internet, } \\
\text { I will feel enthusiastic. }\end{array}$ & 5.15 & 1.93 \\
\hline 16 & $\begin{array}{l}\text { I will feel enthusiastic about doing a presentation assignment in } \\
\text { front of my friends. }\end{array}$ & 5.18 & 1.78 \\
\hline
\end{tabular}


Based on the information retrieval ability (1-4) on information literacy competency, based on Table 3.1, the data shows that respondents' ability of information retrieval at a moderate level $(\overline{\mathrm{x}}=5.1)$. The ability of respondents to downloading information shows a medium level $(\overline{\mathrm{x}}=$ 5.06). Meanwhile, the ability to use search strategies and the ability to find physical/ offline reference sources is at a moderate level $(\overline{\mathrm{x}}=4.46 \& 4.69)$. Furthermore, students also have a moderate level of ability to use the right keywords to find information $(\overline{\mathrm{x}}=5.1)$.

Furthermore, Table 3.1 illustrates that based on the information evaluation ability (5-8), the data show that respondents have abilities at a moderate level $(\overline{\mathrm{x}}=5.06)$. In the first indicator, namely the ability to assess the quality of information, the data shows that the respondent has the ability at a moderate level $(\overline{\mathrm{x}}=4.41)$. Meanwhile, respondents' ability to search for relevant information is at a medium level $(\overline{\mathrm{x}}=5.62)$. The next indicator is the ability to assess the quality of the reference and the ability to distinguish opinions and facts from respondents who are also at a moderate level $(\overline{\mathrm{x}}=4.87 \& 5.34)$.

On the other hand, in the information processing ability (9-12) in Table 3.1, the data indicate that respondents have a moderate level of ability $(\overline{\mathrm{x}}=5.35)$. The ability to identify the scientific information structure and the ability to adapt the source of scientific information from respondents is at a moderate level $(\overline{\mathrm{x}}=5.62 \& 5.66)$. Furthermore, the self-efficacy respondents who identify the scientific information structure are at a moderate level $(\bar{x}=4.73)$. In the last indicator, namely self-efficacy adapting scientific information sources, the data is shown on ( $\overline{\mathrm{x}}$ $=5.41$ ), which indicates that respondents have a moderate level of ability.

Finally, the data on the sub-communication competency and student information dissemination (13-16) shows that respondents have the moderate ability $(\overline{\mathrm{x}}=5.07)$. Respondents' ability to manage the document is at a medium level $(\overline{\mathrm{x}}=5.76)$. Furthermore, the respondents' belief in professional academic ethics is also at a moderate level $(\overline{\mathrm{x}}=4.19)$. On the other hand, the ability to use digital means and the ability to communicate information to respondents are at a medium level $(\overline{\mathrm{x}}=5.18 \& 5.1)$.

Table 2. Information Literacy Competency Viewed from Gender and Ethnicity

\begin{tabular}{lcccc}
\hline \multirow{2}{*}{ Variables } & \multicolumn{2}{c}{ Gender $(\overline{\mathbf{x}})$} & \multicolumn{2}{c}{ Ethnicity $(\overline{\mathbf{x}})$} \\
\cline { 2 - 5 } & $\mathbf{M}$ & $\mathbf{F}$ & Papua & Non-Papua \\
\hline Information retrieval competency & 5.16 & 5.08 & 4.9 & 5.07 \\
Competency of evaluating information & 4.81 & 4.94 & 4.6 & 5.00 \\
Competency of processing information & 4.94 & 5.32 & 5.4 & 4.79 \\
Communication and information & 5.06 & 5.58 & 4.1 & 5.01 \\
dissemination competency & & & & \\
\hline
\end{tabular}

In addition, this study will also identify information literacy competency in terms of gender and ethnicity, which can be seen in Table 3.2. Based on the gender perspective, there are differences between males and females on information literacy competence. In the gender perspective, on average, female has better information literacy competence compare to male ( $\overline{\mathrm{x}}$ $=5.23$ ). Meanwhile, related to ethnicity, there are differences between Papuans and nonPapuans ethnic on the information literacy competence. In general, non-Papuan has slightly better information literacy competence compared to the other ethnicity $(\overline{\mathrm{x}}=4.97)$ 
The next question that the researcher asks respondents is the respondents' strategies of getting their information literacy competency. Figure 3.1-3.5 shows the column chart of the distribution on which respondents obtain information literacy competency. The data obtained from respondents is processed using the number of frequencies to determine the distribution of places where information literacy competencies are acquired. In general, based on Figure 3.13.5 , the majority of respondents obtain information literacy competency from self-learning. The second strategy of the acquisition of information literacy competency is at Class Co Courses. Meanwhile, the strategy of using the library and learning from friends are rank third and fourth.

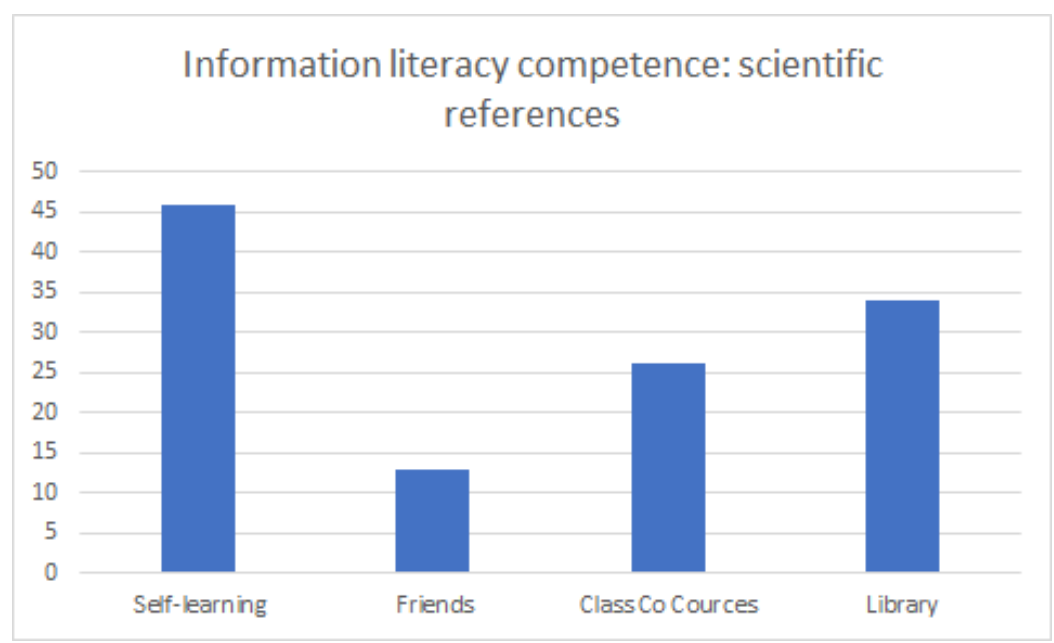

Fig 3. Strategies for Scientific References

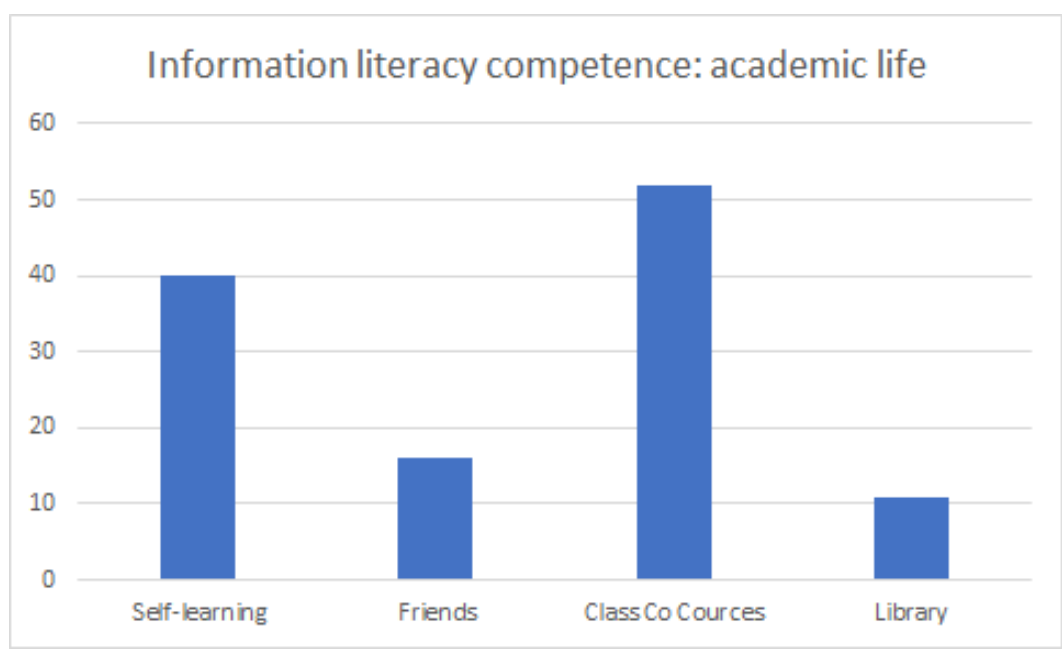

Fig 4. Strategies for Academic Life 


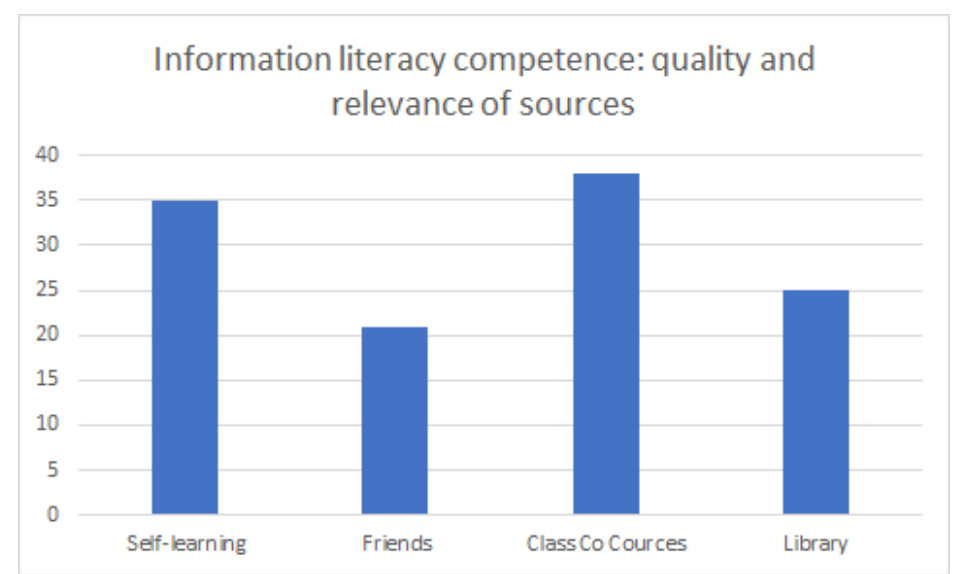

Fig 5. Strategies for Quality and Relevance of Sources

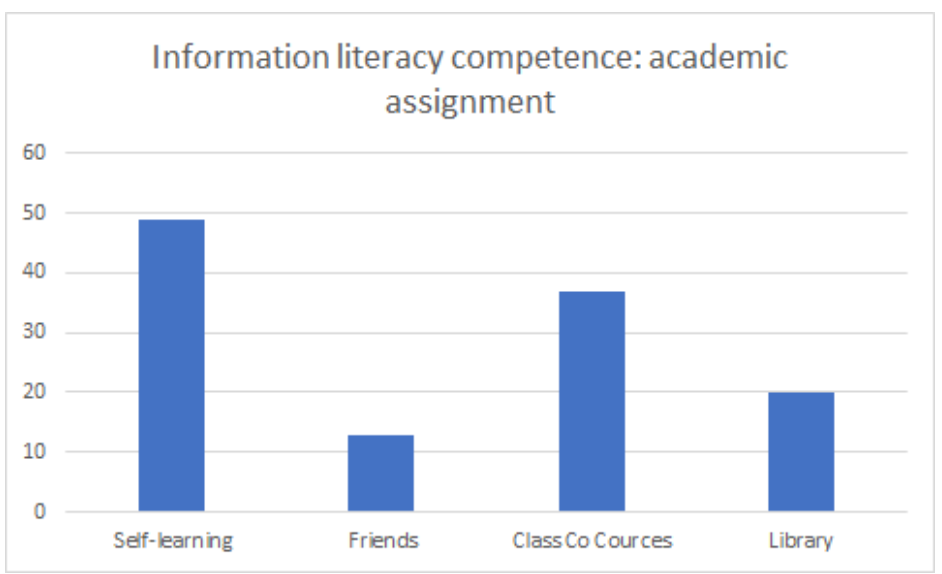

Fig 6. Strategies for Academic Assignment

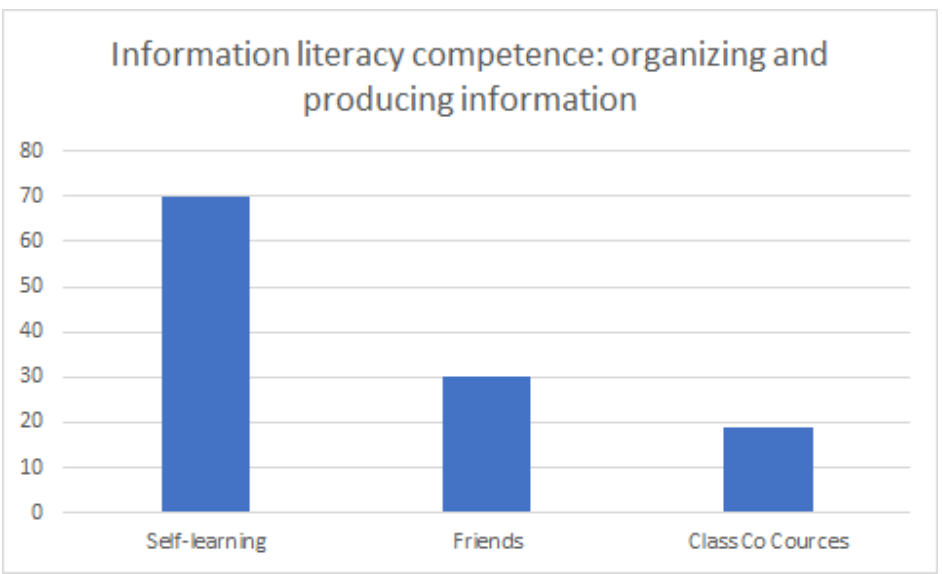

Fig 7. Strategies for Organizing and Producing Information 
The first question of this research is to determine the level of student information literacy competency through self-assessment. Based on the processed data, respondents have the ability to search for information at a moderate level. The ability to search for information is correlated with the ability to evaluate information at a moderate level. Actually, the ability to obtain information and assess information is needed by students to get qualified information from internet sources [33]. With this ability, students can determine the quality and relevance of the information sources obtained. In supporting these two abilities, critical thinking competency are also needed to justify the information obtained [34]. The ability to obtain and evaluate student information at a moderate level is assumed to occur due to their limited exposure to information literacy competency.

Furthermore, data on the ability to process information and disseminate information shows that students have abilities at a moderate level. The student's ability to process and disseminate information correlates with the ability to obtain and evaluate information. The four indicators of information literacy competencies are interrelated so that if one ability is at a moderate level, the other competencies may also be at a moderate level. The findings of this study should be of concern not only to students but also to universities. Results from previous research have revealed that students are burdened with poor information literacy competency because they have problems finding the right reference sources to use the information as material for academic assignments [35].

Meanwhile, regarding research questions related to gender, this study found that females have better information literacy competency than males. On the other hand, non-Papuan students have a better competency in information literacy than other ethnic groups. The findings are in line with findings from previous studies that the ability of students to read and write academic texts is closely influenced by gender and culture [36]. Moreover, gender is also influential in acquiring information literacy competency $[15,16]$.

In addition, regarding the strategies of obtaining information literacy competency by students, self-learning is in the first place. This finding is interesting because the COVID-19 epidemic is thought for having an effect on student learning strategies, which initially focused on the lecturing method to self-learning. In the second place, the class co course role cannot be separated from the formation of students' information literacy competency. Through distance learning, students may learn information literacy competency. Other findings also indicate that the learning method with friends is an option for students to improve information literacy competency. Finally, the library is the last place for students to acquire information literacy competency. This situation may have occurred because, during the COVID-19 epidemic period, libraries in universities are restricted or shut down their services.

\section{Conclusion}

Based on this study, the self-assessment of students' information literacy competence during the COVID-19 pandemic in four tertiary institutions in Indonesia-Papua New Guinea border is at a moderate level. Continuous action is needed to respond to the findings of this study, considering the learning model has been transformed from face-to-face learning to 
distance learning during the COVID-19 epidemic. In responding to distance learning, students need information literacy competency to participate in the learning process. Other findings also show that particular gender and ethnicity have better information literacy competency. On the other hand, the findings of this study also show that student's majority acquire information literacy competency by using the self-learning strategy. Long-term policies must be taken by the institution to optimize the role of libraries and teaching staff to improve students' information literacy competency. Policies can be pursued by improving the curriculum or creating a learning model to improve information literacy competency that are ethnic and gender friendly. Furthermore, the blended learning model has promising potential to be applied because of the limited infrastructure owned by students in participating in distance learning.

Acknowledgments. My gratitude is expressed to Minister of Research and Technology BRIN, Republic of Indonesia as this research is funded by Penelitian Dosen Pemula Scheme (No: 119.10/UN52.8/LT/2020) in 2020. The authors also extend gratitude to Prof. Dr. Philipus Betaubun, M.T as Rector of Universitas Musamus.

\section{References}

[1] Wickramasinghe, N. Chandra, et al. Growing Evidence against Global Infection-Driven by Personto-Person Transfer of COVID-19. VirolCurr Res, 2020, 4.1.

[2] Bao, W. COVID-19 and online teaching in higher education: A case study of Peking University. Human Behavior and Emerging Technologies, 2020. vol. 2, no. 2, pp. 113-115,

[3] Sintema, E. J. Effect of COVID-19 on the performance of grade 12 students: Implications for STEM education. Eurasia Journal of Mathematics, Science and Technology Education, 2020. vol. 16, no. 7, p. em1851.

[4] Iyer, P., Aziz, K., and Ojcius, D M. Impact of COVID-19 on dental education in the United States. Journal of Dental Education, 2020, 84.6: 718-722.

[5] Chick, R. C. et al. Using technology to maintain the education of residents during the COVID-19 pandemic. Journal of Surgical Education, 2020.

[6] Baba, A. M. A., Achbani, A., and Kharbach, A. Mobile learning in Higher education: Unavoidable alternative during COVID-19. Aquademia, 2020. vol. 4, no. 1, p. ep20016.

[7] Toquero, C. M. Challenges and opportunities for higher education amid the COVID-19 pandemic: The Philippine context. Pedagogical Research, 2020. vol. 5, no. 4.

[8] White, A. M. J. Information Literacy and Critical Thinking in Higher Education: Some Considerations. Handbook of Research on Critical Thinking and Teacher Education Pedagogy: IGI Global. 2019, pp. 367-381.

[9] Dolničar, D. and Podgornik, B. B. Information Literacy of University Freshmen, and Differences in ICT Use, Internet Confidence and Motivation. In: European Conference on Information Literacy. Springer, Cham, 2018. p. 254-263.

[10] Almanthari, A., Maulina, S., and Bruce, S. Secondary School Mathematics Teachers' Views on Elearning Implementation Barriers during the COVID-19 Pandemic: The Case of Indonesia. Eurasia Journal of Mathematics, Science and Technology Education. 2020. vol. 16, no. 7, p. em1860.

[11] Rahiem, M. D. The Emergency Remote Learning Experience of University Students in Indonesia amidst the COVID-19 Crisis. International Journal of Learning, Teaching and Educational Research. 2020. vol. 19 , no. 6 , pp. 1-26.

[12] Abidah, A., Hidaayatullaah, H. N., Simamora, R. M., Fehabutar, D., and Mutakinati, L. The Impact of Covid-19 to Indonesian Education and Its Relation to the Philosophy of "Merdeka Belajar". Studies in Philosophy of Science and Education. 2020. vol. 1, no. 1, pp. 38-49.

[13] Wingate, U. and Tribble, C. The best of both worlds? Towards an English for Academic Purposes/Academic Literacies writing pedagogy. Studies in higher education. 2012. vol. 37, no. 4, pp. 481-495. 
[14] Lillis, T. M. Student writing: Access, regulation, desire. Psychology Press. 2001.

[15] Gravill, J. I., Compeau, D. R. and Marcolin, B. L. Experience effects on the accuracy of self-assessed user competence. Information \& Management. 2006. vol. 43, no. 3, pp. 378-394.

[16] Hohlfeld, T. N., Ritzhaupt, A. D., and Barron, A. E. Are gender differences in perceived and demonstrated technology literacy significant? It depends on the model. Educational Technology Research and Development. 2013. vol. 61, no. 4, pp. 639-663.

[17] Nahyun, K. and Hana, S. Personality traits, gender, and information competency among college students. Malaysian Journal of Library \& Information Science. 2017. vol. 16, no. 1, pp. 87-107.

[18] Mahmood, K. Relationship of students' perceived information literacy skills with personal and academic variables. Libri. 2013. vol. 63, no. 3, pp. 232-239.

[19] Tsai, M.-J. and Tsai, C.-C. Junior high school students' Internet usage and self-efficacy: A reexamination of the gender gap. Computers \& Education. 2010vol. 54, no. 4, pp. 1182-1192.

[20] Yi, Z. International student perceptions of information needs and use. The Journal of Academic Librarianship. 2007. vol. 33, no. 6, pp. 666-673.

[21] Shenton, A. K. and Fitzgibbons, M. Making information literacy relevant. Library Review, 2010.

[22] J. Beard and P. Dale, "Library design, learning spaces and academic literacy," New library world, 2010.

[23] Pinto, M. Assessing disciplinary differences in faculty perceptions of information literacy competencies. Aslib journal of information management. 2016.

[24] Lahlafi, A. E., Rushton, D., and Stretton, E. Active and reflective learning initiatives to improve web searching skills of business students. Journal of information literacy. 2012. vol. 6, no. 1, pp. 35-49.

[25] Gunn, C. Hearne, S. and Sibthorpe, J. Right from the start: A rationale for embedding academic literacy skills in university courses. Journal of University Teaching \& Learning Practice. 2011. vol. 8 , no. 1 , p. 6 .

[26] Guzmán-Simón, F., García-Jiménez, E., and López-Cobo, I. Undergraduate students’ perspectives on digital competence and academic literacy in a Spanish University. Computers in Human Behavior. 2017. vol. 74, pp. 196-204.

[27] Akayoglu, S., Satar, H. M., Dikilitas, K., Cirit, N. C., and Korkmazgil, S. Digital literacy practices of Turkish pre-service EFL teachers. Australasian Journal of Educational Technology. 2020.

[28] Shannon, C., Reilly, J. and Bates, J. Teachers and information literacy: understandings and perceptions of the concept. Journal of Information Literacy. 2019. vol. 13, no. 2, pp. 41-72.

[29] Mueller, J. Rubrics. Authentic Assessment Toolbox (Accessed September 12, 2013) url: http://jfmueller. faculty. noctrl. edu/toolbox/rubrics. htm, 2012.

[30] Ross, M., Perkins, H., and Bodey, K. Information literacy self-efficacy: The effect of juggling work and study. Library \& Information Science Research. 2013. vol. 35, no. 4, pp. 279-287.

[31] Goodfellow, R. Literacy, literacies and the digital in higher education. Teaching in Higher Education. 2011. vol. 16, no. 1, pp. 131-144.

[32] Pinto, M. Design of the IL-HUMASS survey on information literacy in higher education: A selfassessment approach. Journal of information science. 2010. vol. 36, no. 1, pp. 86-103.

[33] Williams, P., Fieldhouse, M., and Rowlands, I. The Google generation: myths and realities about young people's digital information behaviour. Digital Consumers. Reshaping the Information Profession, Facet Publishing, London. 2008. pp. 159-92,

[34] Scott, L. K. and Simmons, S. R. Incorporating primary literature in undergraduate crop science courses. Journal of Natural Resources \& Life Sciences Education. 2006. vol. 35, no. 1, pp. 225-233.

[35] MacMillan, M. and MacKenzie, A. Strategies for integrating information literacy and academic literacy. Library Management. 2012.

[36] Lillis, T. M. Student writing: Access, regulation, desire. Routledge, 2002. 